\title{
POTENTIAL OF LOSS OF ORGANIC FERTILIZER IN LOWLAND RICE FARMING IN KLUNGKUNG DISTRICT, BALI
}

\author{
I Nengah Muliarta ${ }^{1 \bullet}$, Jhon Hardy Purba ${ }^{2}$ \\ ${ }^{1}$ Program Studi Teknik Industri, Universitas Mahendradatta, Denpasar \\ ${ }^{2}$ Program Studi Agroteknologi, Universitas Panji Sakti, Singaraja \\ `Email korespondensi: nengahmuliarta@gmail.com
}

\begin{abstract}
Rice straw is a resource that can be used as organic fertilizer. The fact in the field was still found that rice straw was wasted, one of which was burned. A study was conducted through a method of observation and survey involving rice paddy farmer groups in 3 sub-districts in the district of Klungkung, namely Banjarangkan, Klungkung and Dawan. The aim of the research was to know the production of rice straw waste and the potential of wasted organic fertilizer in intensive rice cultivation. Based on the results obtained the production of dried straw waste in each harvest about 10.21 tons/ha. Farmers do not utilize rice straw as compost by reason, not knowing how to compost. There were $30.34 \%$ of farmers who got the wrong knowledge that an easy way to return rice straw to the ground is by burning it. Due to the research result, straw burning wasted around 5,887,086 - 7,888.7 tons of organic fertilizer.
\end{abstract}

Keywords: rice straw; organic fertilizer; waste; compost

\section{INTRODUCTION}

Bali had 79,526 ha of paddy fields with an average of 6.22 tons/ha of paddy productivity. Klungkung Regency was one of the rice producing regencies and was the location of the implementation of the corn and soybean development program "Pajale". Klungkung Regency has 3,844 ha of paddy area with an average of 6,61 tons/ha of paddy productivity (BPS Bali, 2017).

Rice includes clumped food plants originating from two continents, Asia and West Africa (Umadevi et al., 2012). In rice cultivation, rice straw waste is produced, where production in each harvest is strongly influenced by the location and type of variety planted, weather, planting methods and fertilization (Rosmiza et al., 2014a). It is estimated that only $20 \%$ of this waste is utilized for industrial and domestic use. In developing countries, especially Southeast Asia, partially ruminant animal feed uses rice straw (Oladosu et al., 2016). In reality, there are not many farmers who use the rice straw directly as feed or process straw into organic fertilizer (compost) (Afriani, 2013).

Burning rice straw by farmers, commonly found in the field, is the reason for speeding up the processing of the land to pursue the next planting period. Burning rice straw in several areas aims to avoid the spread of pests and diseases (Rosmiza et al., 2014a). The practice of open straw burning has been proven to be a significant source of carbon emissions during the harvest season. The open burning of straw has also significantly affected air quality (Chang et al., 2013). Rice straw management is needed to avoid burning to get economic and environmental benefits (Kanokkanjana and Garivait, 2013).

Rice straw chemically contains lignocellulose compounds, which are composed of cellulose (35-50\%), hemicellulose (20-35\%) and lignin (10-25\%) and other substances (Saha, 2003). Rice straw also contains nutrients that are useful for plants, so the return of rice straw to the soil is one of the important efforts in maintaining soil nutrient stability and to meet crop nutrient needs (Pavithira et al., 2017). Nearly $40 \%$ of element N, 30 to $35 \%$ of $\mathrm{P}, 80-85 \%$ of element $\mathrm{K}$, and $40-45 \%$ of element $\mathrm{S}$ taken by rice plants from the soil are in rice straw (Dobermann and Fairhurst, 2002). Utilizing agricultural waste into organic fertilizer (compost) not only provides essential nutrients for plants, but also improves soil fertility and is an effort to preserve the 
environment through waste management (Golabi et al., 2004). The application of liquid biological fertilizers significantly increases the growth and yield of shallots (Purba et al., 2020).

An estimate of straw production and potential loss of organic fertilizer is important so that anticipatory plans can be made. This estimate also becomes important as consideration, preparation and development of rice straw processing. If the potential for loss of organic matter due to straw burning is known, the amount of organic fertilizer that needs to be added can be predicted. This will reduce the use of inorganic fertilizers, and improve soil fertility. The purpose of this study was to determine the potential loss of organic matter due to burning rice straw in klungkung regency, and to estimate the need for additional organic fertilizers to replace these losses.

\section{METHODS}

The method used in this research is observation and survey (Sugiyono, 2016). Observations were made to determine the production of rice straw using 5 x $5 \mathrm{~m}$ size tiles. Production measurements were carried out in August to November 2016 in 3 districts in Klungkung Regency (Dawan, Klungkung and Banjarangkan). The Klungkung area is chosen because Klungkung is one of the regions included in the national program for the development of rice, corn and soybean (Pajale). The survey was also conducted in 3 sub-districts in Klungkung during May-June 2017. The location was chosen because it represents the pattern of rice cultivation and harvesting in the Klungkung Regency. Two Subak groups were randomly selected in each sub-district, the number of respondents was 10 percent of each Subak group member (Arikunto, 2010). The Subak group that is the research sample is presented in Table 1. The purpose of the survey was to determine the use of rice straw by farmers and examine the composition of rice straw. $\underline{\text { Table 1. Subak groups of research samples }}$

\begin{tabular}{llll}
\hline Sub-district & Subak & $\begin{array}{c}\text { Number } \\
\text { of } \\
\text { farmers }\end{array}$ & $\begin{array}{c}\text { Number } \\
\text { of } \\
\text { respond } \\
\text { ents } \\
(10 \%)\end{array}$ \\
\hline Banjarangkan & Tegehan & 157 & 16 \\
& Lepang & 154 & 15 \\
Klungkung & Gembalan & 170 & 17 \\
& Jero Kuta & 110 & 11 \\
Dawan & Pesinggahan & 186 & 19 \\
& Sampalan & 110 & 11 \\
\hline Total number of respondents & 887 & 89 \\
\hline \multicolumn{4}{l}{} \\
\hline
\end{tabular}

The questionnaire in the survey research before it was used was tested to members of the Manduang Subak Group, Klungkung District. There were 15 questions raised by 13 farmers found in the field. The results of the validity test with a significance level of 0.05 percent indicate that of the 15 questions, there were 9 questions declared valid. Questions that were declared valid have a t-count between 2.131 to 6.978 , while the t-table is 1.796. The reliability test results show that the reliability test value of 0.845 or above 0.60 , so the instrument can be said to be reliable (Latan, 2014).

Analysis of fiber content in rice straw was conducted at the Laboratory of the Faculty of Agricultural Technology, Udayana University, P.B. Sudirman street, Denpasar. Analysis of cellulose, hemicellulose, lignin and silica content in the Animal Nutrition and Feed Laboratory, Faculty of Animal Husbandry, Udayana University. This data is needed to determine the level of ease of the straw decomposition process. Analysis of N, $\mathrm{P}, \mathrm{K}$ and $\mathrm{C}$-organic of rice straw to found out the nutritional content, at the Laboratory of the Indonesian Spice and Medicinal Research Institute (Balittro) Tentara Pelajar street no. 3 Bogor West Java.

Analysis of the chemical composition of rice straw was carried out by taking a sample of $100 \mathrm{~g}$ of rice straw for analysis in the laboratory to determine the fiber content and macro nutrient content in rice straw. The rice straw used comes from the Ciherang variety which was taken from the all subak sample 
evenly. The rice straw used was 105 days after planting (DAT).Data processing in this study used Microsoft Excel 2010 software. Data collected were analyzed descriptively. The data is then tabulated and presented in the form of a frequency and percentage table.

\section{RESULTS AND DISCUSSION}

Based on the results of the sampling yield using $5 \times 5$ meters of sampling area, we found that the average production of harvested unhusked rice in Klungkung Regency reached 8.41 tons/ha, higher than average of Bali (6.22 tons/ha), and the average production of harvested hay reached 10.75 tons/ha. Data on average grain and straw production in each regency is presented in Table 2.

Table 2. Average production of harvested unhulled rice and dry straw harvested per district

\begin{tabular}{lcc}
\hline Sub-district & $\begin{array}{c}\text { Harvest } \\
\text { dry grain } \\
\text { productio } \\
\mathrm{n} \\
\text { (tons/ha) }\end{array}$ & $\begin{array}{c}\text { Dry harvest } \\
\text { straw } \\
\text { production } \\
\text { (tons/ha) }\end{array}$ \\
\hline Banjarangkan & 8,83 & 11,74 \\
Klungkung & 8,63 & 10,51 \\
Dawan & 7,76 & 10,04 \\
\hline Average & 8,41 & 10,75 \\
\hline
\end{tabular}

By the magnitude of the correction of rice field bunds for Klungkung Regency which was $5 \%$, the average grain production in Klungkung Regency was 7.99 tons/ha per harvest and the average production of dry straw harvested was 10.21 tons/ha per harvest. A comparison was made for each production of $1 \mathrm{~kg}$ of unhusked rice produced $1.3 \mathrm{~kg}$ of dry rice straw. These results were the same as previous studies which stated that each production of $1 \mathrm{~kg}$ of grain produced $1-1.5 \mathrm{~kg}$ of rice straw (Binod et al., 2010; Adam, 2013).There was no farmer in Klungkung Regency who uses rice straw as organic fertilizer through the composting process. Rice straw was only used by farmers as mulch (Table 3).
Table 3. Management of rice straw by farmers in Klungkung

\begin{tabular}{clc}
\hline No. & $\begin{array}{l}\text { Management of rice } \\
\text { straw }\end{array}$ & Percentage (\%) \\
\hline 1. & $\begin{array}{l}\text { Organic } \\
\text { (compost) }\end{array}$ & fertilizer \\
2. & Animal feed & - \\
3. & Immersion & - \\
4. & Burning & - \\
5. & Mulch & 30,34 \\
\hline Total & & 69,66 \\
\hline
\end{tabular}

The main reason farmers do not use rice straw as organic fertilizer was not knowing how to compost rice straw. Even though the nutritional content of straw is quite good (Table 4). The second reason was the limited labor that helps in composting and the third reason was the limited time, because besides farming, farmers in Klungkung were also involved in religion and culture activities.

Farmers in Klungkung Regency were dominant $(74.16 \%)$ do not know if rice straw can be composted. This result was in line with Sardjono et al. (2012) which states that farmers' knowledge was a major factor in the utilization and processing of straw waste into organic fertilizer. Based on the results of laboratory analysis rice straw contains nutrients needed by plants (Table 4). So a big loss if the nutrient content was wasted through burning straw. Indeed, the high $\mathrm{C} / \mathrm{N}$ content of straw makes it slow to decompose. However, this obstacle can actually be reduced by the use of decomposition bacteria which are available in agricultural shops.

Table 4. Rice straw content (per 100 g)

\begin{tabular}{llll}
\hline No & Parameters & Content & Remarks \\
\hline 1. & C/N & 34,96 & high \\
2. & C-Organic & $35,31 \%$ & moderate \\
3. & $\mathrm{~N}$ & $1,01 \%$ & moderate \\
4. & $\mathrm{P}$ & $0,17 \%$ & moderate \\
5. & $\mathrm{~K}$ & $3,13 \%$ & low \\
6. & $\mathrm{pH}$ & $6,13 \%$ & low \\
7. & Water content & $73.0 \%$ & - \\
\hline
\end{tabular}

Note: remarks* compared with industry national standard (SN)I) No. 19-7030-2004 related to compost specification from domestic organic waste. 
Farmers tend to $(69.66 \%)$ use rice straw as mulch, especially when farmers plant crops (Table 3). Rice straw mulch was needed by farmers when planting crops such as soybeans, chilies, long beans, cucumbers, watermelons, flowers and green vegetables. This result was the same as the statement of Rosmiza et al. (2014b) which states that rice straw was generally used as mulch when growing vegetables and horticulture. The use of rice straw mulch was done by farmers for several reasons such as to suppress the growth of pests, reduce evaporation and reduce the cost of purchasing plastic mulch (Setiyaningrum, 2019).

The use of rice straw as animal feed was also not done by farmers. This happens because of the low ownership of cattle, where $33.71 \%$ of farmers do not have cattle, $24.72 \%$ of farmers only have 1 cattle and $27.00 \%$ have 2 cattle. Farmers reasoned that rice straw feed was not good for animal health because of its low protein $(2.72 \%)$ content and forage feed in the Klungkung region, which was always available every year. The low protein content of straw can be seen from the results of laboratory tests of rice straw of Ciherang variety which was taken from the all subak sample evenly, as presented in Table 5.

Table 5. Fiber content of rice straw

\begin{tabular}{llc}
\hline No & Parameters & Content \\
\hline & & \\
\hline 1. & Water content & $73,06 \%$ \\
2. & Ash levels & $5,09 \%$ \\
3. & Protein & $2,72 \%$ \\
4. & Fat & $0,38 \%$ \\
5. & Carbohydrate & $17,93 \%$ \\
6. & Coarse fiber & $7.72 \%$ \\
\hline
\end{tabular}

Lignin and silica content in rice straw limits the digestibility of livestock (Oladosu et al., 2016) and lignin in plant cell walls limits the ability of rumen microbes to degrade rice straw (Wang and McAllister, 2002). The results of laboratory tests on the lignocellulose content of rice straw were presented in Table 6. According to Fatmawati et al. (2005) that the rice straw content is based on dry matter $89.57 \%$, crude protein $3.2 \%$, crude fiber $32.56 \%$, fat $1.33 \%$, cellulose $40.80 \%$ hemicellulose $26.62 \%$, and lignin $5.78 \%$. The straw protein content in the study site was lower than the results of the study by Fatmawati (2005), but the lignin was higher. Low protein content and high lignin are one of the causes of the low use of straw as an organic fertilizer.

Table 6. Lignocellulose content of rice straw

\begin{tabular}{lll}
\hline No & \multicolumn{1}{c}{ Parameters } & Content \\
\hline 1. & Cellulose & $30,47 \%$ \\
2. & Hemicellulose & $18,16 \%$ \\
3. & Lignin & $21,60 \%$ \\
4. & Silica & $16,60 \%$ \\
5. & Fenol & $7,73 \mathrm{mg} / 100 \mathrm{gr} \mathrm{GAE}$ \\
\hline
\end{tabular}

In practice in the field, none of the farmers do rice straw planting. Farmers were reluctant to immerse rice straw that was produced because immersion of fresh rice straw after harvest makes it difficult when doing land management. Immersion of straw also has an itching effect on the skin during land cultivation. Decomposition of organic material at an early stage produces organic acids such as oxalic, formic and maleic acids (Kumari et al., 2008). As an organic acid, oxalic acid can cause negative effects on the skin in the form of skin and eye irritation (Dakshene et al., 2013).

There were around $30.34 \%$ of farmers who burn rice straw with the reason to speed up land management and discuss pests. There were also farmers who burn straw because based on the knowledge obtained that the burning ash of rice straw can be beneficial for soil fertility. Burning rice straw was one of the early applications of organic farming that comes from the experience of farmers (Dobermann and Fairhurst, 2002). Though burning straw has a negative impact because it can damage the soil structure and reduce soil microbial activity. By burning rice straw, it can lose N (up to 80\%), P (25\%), K (21\%) and $\mathrm{S}(4-60 \%)$ and lose soil organic matter (Mandal et al., 2004). 
In a study in Taiwan using remote sensing showed that there was open burning of rice straw about $27.3 \%$ of the existing rice field area (Chang et al., 2013).

The area of rice fields in Klungkung Regency is 3,844 ha (BPS Bali, 2017). From the sampling results obtained dry straw production of 10.21 tonnes / ha / harvest, so that overall dry straw production in one harvest season in Klungkung reached 39,247.24 tonnes. This rice straw waste should be reused as organic fertilizer to the land where the straw originated. According to (Purba et al., 2018), organic fertilizers also have benefits in providing media for the life of beneficial microorganisms for soil fertility and reducing porosity in sandy soil and helping aeration in clay soils.

Based on the survey results, it was found that $30.34 \%$ of the farmers burned rice straw. Thus, in one harvest season 11,774.17 tons of compost raw material are wasted. According to Gustiani et al. (2014), if rice straw was able to be processed optimally, every 1 ton of straw can produce $1 / 2$ tons to $2 / 3$ tons of compost. If there were $11,774,172$ tons of rice straw, the amount of compost produced will be around 5,887,086 tons to 7,888.7 tons. So the amount of organic fertilizer (compost) that was wasted in one harvest season in Klungkung Regency reaches 5,887,086 tons to $7,888.7$ tons.

Burnt rice straw when composted will be able to meet the needs of organic fertilizer and reduce the use of inorganic fertilizers. Ragályi et al. (2009) and Sutrisno (2014) stated the use of organic fertilizer in organic rice cultivation was around 8-10 tons / ha. If based on the use of a maximum dose of 10 tons / ha, the amount of organic fertilizer wasted during one harvest season can meet the minimum fertilizer requirements for an area of 588.71 ha or $15.31 \%$ of the total area of rice fields in Klungkung Regency.

The implication of this research was the need for socialization of the utilization of rice straw to farmers so that no more rice straw was burned. Farmers need to be given knowledge about how to compost rice straw that was easy, practical, fast and produces quality compost. Further research is needed on the factors that cause low levels of straw protein, which means low levels of $\mathrm{N}$, and high levels of lignin, which causes the straw to break down slowly. In addition, it was also necessary to conduct further research related to the use of rice straw, such as the use of straw lignin as an antimicrobial, and rice straw as bioethanol.

\section{CONCLUSION}

The potential of organic fertilizer raw material in the form of rice straw in one harvest reaches around 10.21 tons / ha, or from every $1 \mathrm{~kg}$ of grain produced $1.3 \mathrm{~kg}$ of rice straw. None of the farmers in the research location used rice straw as compost, because they did not know how to compost rice straw, limited labor and time constraints. About $30.34 \%$ of farmer's burn rice straw because based on knowledge gained by generation, burning was a simple way to return rice straw to the ground. The potential of organic fertilizer wasted in one harvest season in rice cultivation in Klungkung Regency was around 5,887.086-7,888.7 tons. The wasted potential can at least meet the needs of organic fertilizer for $15.31 \%$ of the area of rice fields in Klungkung Regency.

\section{Acknowledgments}

The author would like to thank the Klungkung Regency Government, especially the Klungkung Regency Agriculture Office who has given permission to conduct research. The author also thanks the heads of several "Subaks" whose members are respondents, including the Chairman of the Pesinggahan-Dawan (Ketut Suwitra), Chairperson of the Gembalan-Klungkung Subak (Wayan Kartika), and the Chairperson of Tegehan-Banjarangkan Subak (Wayan Mandra). Special thanks also to Darma Farm owner (Ketut Darmawan) who helped a lot in conducting the survey and interview process. 


\section{REFERENCES}

Adam, J. (2013). Alternatives to Open-Field Burning on Paddy Farms. Options, 18, 15.

Afriani, H., Dianita, R., \& Idris, N. (2013). Optimalisasi Pemanfaatan Limbah Pertanian Melalui Pembuatan Kompos dan Silase Pada Kelompok Peternak Sapi dan Kelompok Wanita Petani Holtikultura. Jurnal Pengabdian Pada Masyarakat, 55 (1), 21-25.

Arikunto. S. (2010). Prosedur Penelitian : Suatu Pendekatan Praktik, Edisi Revisi. Cetakan 14, Rineka Cipta, Jakarta.

Binod, P., Sindhu, R., Singhania, R.R., Vikram, S., Devi, L., Nagalakshmi, S., Kurien, N., Sukumaran, R.K., \& Pandey, A. (2010). Bioethanol production from rice straw : An Overview. Bioresource Technology, 101, 4767-4774.

BPS Bali. (2017). Provinsi Bali Dalam Angka 2017. BPS Provinsi Bali. No. Publikasi: 51560.1705, 205-233.

Chang, C.H., Liu, C.C., \& Tseng, P.Y. (2013). Emissions Inventory for Rice Straw Open Burning in Taiwan Based on Burned Area Classification and Mapping Using Formosat-2 Satellite Imagery. Aerosol and Air Quality Research, 13, 474-487.

Dakshene, M., Rani, A., \& Sharma, P.D. (2013). International Journal of Chemical Studies. International Journal of Chemical Studies, 1(4), 114-120.

Dobermann, A., \& Fairhurst, T.H. (2002). Rice Straw Management. Better Crops International, 16, 7-11.

Fatmawati. 2005. Komposisi Kimia Fraksi Jerami Padi (Daun, Pelepah dan Batang). Skripsi. Fakultas Peternakan Universitas Andalas, Padang.

Golabi, M.H., Denney, M.J., \& Iyekar, C. (2004). Use of Composted Organic Wastes As Alternative to Synthetic Fertilizers for Enhancing Crop Productivity and Agricultural Sustainability on The Tropical Island of Guam.
Gustiani, E., Nurhati, I., \& Haryati, Y. (2014). Pemanfaatan Limbah Pertanian Sebagai Pakan Ternak Dalam Sistem Usahatani Tanaman Ternak. Balai Pengkajian Teknologi Pertanian Jawa Barat. Lokakarya Nasional Pengembangan Jejaring Litkaji Sistem Integrasi Tanaman-Ternak, 51-54.

Kanokkanjana, K., \& Garivait, S. (2013). Alternative Rice Straw Management Practices to Reduce Field Open Burning in Thailand. International Journal of Environmental Science and Development, 4 (2), 119-123.

Kumari, A., Kapoor, K.K., Kundu, B.S., \& Mehta, R.K. (2008). Identification of organic acids produced during rice straw decomposition and their role in rock phosphate solubilization. Plant, Soil and Environment, 54 (2), 7277.

Latan, H. (2014). Aplikasi Analisis Data Statistik untuk Ilmu Sosial Sains Dengan STATA. Cetakan Kesatu. Penerbit Alfabeta, Bandung.

Mandal, K.G., Misra, A.K., Hati, K.M., Bandyopadhyay, K.K., Ghosh, P.K., \& Mohanty, M. (2004). Rice residuemanagement options and effects on soil properties and crop productivity. Food, Agriculture \& Environment, 2 (1), 224231.

Oladosu, Y., Rafii, M.Y., Norhani, A., Magaji, U., Hussin, G., Ramli, A., \& Miah, G. (2016). Fermentation Quality and Additives: A Case of Rice Straw Silage. Biomed Research International, 2016, 1-14.

Pavithira, E., Sirisena, D. N., \& Herath, H. M. S. K. (2017). Effect of Potassium Fertilizer Split Applications together with Straw on Optimum Level in Leaf and Stem of Rice. The Journal of Agricultural Sciences, 12 (1), 24-33.

Purba, J.H., Wahyuni, P.S., Zulkarnaen, Sasmita, N., Yuniti IG.D., Pandawani, N.P. 2020. Growth and yield response of shallot (Allium ascalonicum L. var. Tuktuk) from different source materials 
applied with liquid biofertilizers. Nusantara Bioscience, Vol. 12 No. 2: 127-133.

Purba, J. H., Parmila, I. P., \& Sari, K. K. (2018). Pengaruh Pupuk Kandang Sapi dan Jarak Tanam terhadap Pertumbuhan dan Hasil Kedelai (Glycine max L. Merrill) Varietas Edamame. Agro Bali: Agricultural Journal, Vol. 1 No.2: 6981.

Ragályi, P., Rékási, M., Lonţariš, Z., Kovațeviš, V. 2009. Composted slaughterhouse waste as organic ertilizer. Proceedings of the 44th Croatian \& 4th International Symposium on Agriculture, Croatia, 16-20 February 2009.

Rosmiza, M.Z., Davies, W.P., Rosniza, A.C.R., Mazdi, M., Jabil, M.J., WanToren, W.Y., \& Che Rosmawati, C.M. (2014a). Farmers' Participation in Rice Straw-Utilisation in the MADA Region of Kedah, Malaysia. Mediterranean Journal of Social Sciences, 5 (23), 229237.

Rosmiza, M.Z., Davies, W.P., Rosniza, A. C.R., Mazdi, M., \& Jabil, M.J. (2014b). Farmers' Knowledge on Potential Uses of Rice Straw: An assessment in MADA and Sekinchan, Malaysia. Malaysian Journal of Society and Space, 10 (5), 3043.
Sardjono, N., Susilo, B., \& Wignyanto. (2012). Strategi Pengembangan Sistem Produksi Pupuk Organik Pada Unit Pengolahan Pupuk Organik (Uppo) di Desa Bangunsari Kabupaten Ciamis. Jurnal Teknologi Pertanian, 13 (2), 138148.

Setiyaningrum, A. A., A. Darmawati, \& S. Budiyanto. (2019). Pertumbuhan dan produksi tanaman kailan (Brassica oleracea) akibat pemberian mulsa jerami padi dengan takaran yang berbeda. $J$. Agro Complex 3(1):75-83, February 2019.

Sugiyono. (2016). Metode Penelitian Kuantitatif, Kualitatif dan R\&D. Alfabet. Bandung.

Sutrisno, B. (2014).“Optimasi Dosis Pupuk Organik Yang Diaplikasikan Dengan Pupuk Hayati Pada Budidaya Padi Organik" (Skripsi).Bogor : Institut Pertanian Bogor.

Umadevi, M., Pushpa, R., Sampathkumar, K.P., \& Bhowmik, D. (2012). RiceTraditional Medicinal Plant in India. Journal of Pharmacognosy and Phytochemistry, 1 (1), 6-12.

Wang, Y., \& McAllister, T.A. (2002). Rumen Microbes, Enzymes and Feed DigestionA Review. Asian-Australasian Journal of Animal Sciences, 15 (11), 1659-1676. 